PRZEGLĄD RUSYCYSTYCZNY 2020, nr 4(172)

DOI $10.31261 /$ pr.

\title{
JOLANTA BRZYKCY
}

Uniwersytet Mikołaja Kopernika w Toruniu

iD ORCID: http://orcid.org/oooo-0oo1-9563-0723

\section{POETYCKI ŚWIAT LIDII SIENICKIEJ}

\section{THE POETICAL WORLD OF LIDYA SENITSKAYA}

This article concerns Lidya Senitskaya (Volyntseva, 1890?-1975), poet, writer, playwright, translator and literary critic, representative of the „first wave” of the Russian emigration, living until 1939 in Rivne, then (1939-1964) in Warsaw, and later on in the USA. Considered by her contemporaries as one of the most interesting creators of the Russian diaspora in pre-war Poland, she is now regarded by contemporary researchers as an unquestionable poetic individuality. Today Senitskaya is a completely forgotten figure, and her work is unknown to the contemporary readers. The article is an attempt to present the poet's creative silhouette, determine and discuss the subject matter and poetics of her poems.

Keywords: Russian poetry of the "first wave” of Russian emigration, Russian diaspora in Warsaw, Russian women's poetry of the 2oth century, Lidya Senitskaya

Literatura emigracji rosyjskiej „pierwszej fali” w Polsce dwudziestolecia międzywojennego jest coraz lepiej znana, dowodzą tego ukazujące się sukcesywnie od bez mała trzydziestu lat prace polskich i rosyjskich rusycystów. Zgadzają się oni ze sobą, że literatura rosyjskiej diaspory w Polsce ani wagą podnoszonej problematyki, ani też poziomem jej artystycznego ujęcia nie odbiega od utworów, które powstawały w „rosyjskim Berlinie” czy Paryżu

Uwaga polskich emigrantologów od początku skupiała się zarówno na przedstawicielach starszej generacji, znanych na długo przed

1 Zob. np.: Л. Белошевская, П. Мицнер, Л. Флейшман, Лев Гомолицкий и русская литературная жизнь в межвоенной Польше, w: Л. Гомолицкий, Сочинения русского периода. В трех томах, Водолей, Москва 2011, t. I, s. 5-282, i polskie tłumaczenie tego tekstu: P. Mitzner, L. Fleishman, Metamorfozy Lwa (Leona) Gomolickiego, przeł. R. Szczęsny, Wydawnictwo Uniwersytetu Kardynała Wyszyńskiego, Warszawa 2015. 
opuszczeniem ojczystego kraju (Dmitrij Miereżkowski², Dmitrij Fiłosofow ${ }^{3}$, Zinaida Gippius), jak i na twórcach młodszego pokolenia, którzy rozpoczynali twórczość literacką już w Polsce, w latach dwudziestych i trzydziestych (Lew Gomolicki ${ }^{4}$ ). Zajmowano się koryfeuszami literatury emigracyjnej, ale prezentowano także w rozmaitych ujęciach metodologicznych dorobek twórców mniejszego formatu ${ }^{5}$.

Do grona ciekawszych przedstawicieli rosyjskiej diaspory w przedwojennej Polsce badacze zaliczają Lidię Sienicką (Wołyncewą), poetkę, pisarkę i dramatopisarkę, tłumaczkę i krytyka literackiego. Przez współczesnych uważana za twórczynię o niekwestionowanym talen$\mathrm{cie}^{6}, \mathrm{w}$ polskiej rusycystyce ostatnich lat umiejscawiana wśród największych indywidualności rosyjskiej poezji kobiecej „pierwszej fali” w Polsce, Sienicka w zasadzie pozostaje postacią zapomnianą, a jej

${ }^{2}$ F. Sielicki, Mereżkowski w Polsce międzywojennej, „Przegląd Humanistyczny” 1973, nr 3, s. 95-117.

3 I. Obłąkowska-Galanciak, „Gorzkie gody...”. Publicystyczna i literacka działalność Dymitra Filosofowa na emigracji, Wydawnictwo Uniwersytetu WarmińskoMazurskiego, Olsztyn 2001.

4 J. Kulczycka-Saloni, Przedwojenne i powojenne pisarstwo Leona Gomolickiego, „Przegląd Humanistyczny” 1995, nr 4, s. 47-57; W. Skrunda, Rosyjski uchodźca na polskim bruku. O poemacie Lwa Gomolickiego „Warszawa” (1934), „Studia Rossica X” 2000, s. 89-125; tegoż, Echa "gniewnych jambów” w poemacie Lwa Gomolickiego „Warszawa” (1934), „Studia Rossica XI” 2000, s. 187-197; tegoż, Zamyst poematu Lwa Gomolickiego „Warszawa” w świetle inwektyw Karola Radka i nauk mnicha Ewagriusza, „Studia Rossica XII” 2001, s. 215228; Т. П. Агапкина, О. В. Цыбенко, Материалы к биографии Леона (Льва) Гомолицкого, w: В.А. Хорев (red.), Studia Polonorossica: K 8о-летию Елены Захаровны Цыбенко. Сборник статей, Издательство Московского Университета, Москва 2003, s. 468-479.

5 T. Zienkiewicz, Dorofiej Bochan - thumacz literatury polskiej na język rosyjski i krytyk, w: A. Bartoszewicz (red.), Polsko-wschodniostowiańskie powiązania kulturowe, literackie $i$ językowe. 1. Literatura i kultura, Wydawnictwa Wyższej Szkoły Pedagogicznej, Olsztyn 1994, s. 127-134; tegoż, „I nas izgnannikow $w$ molitwach pomiani...”. (O poezji emigracji rosyjskiej $w$ Polsce międzywojennej), „Studia Rossica X”, s. 75-90; I.A. Ndiaye, „Маленькие храбрые женщины...”. Poеzja kobieca pierwszej fali emigracji rosyjskiej w Polsce, „Acta Polono-Ruthenica VII” 2002, s. 45-58; tejże, Русская эмиграционная поэзия на страницах варшавского „Меча” (1934-1939), w: A. Ksenicz (red.), Stowiańszczyzna Wschodnia: twórczość artystyczna a doświadczenia zbiorowe, Wydawnictwo WSP, Zielona Góra 1998, s. 71-76.

${ }^{6}$ Por. pochlebne opinie o Sienickiej w: Н. Волковыский, Русские литераторы в Польше, „Сегодня” 1937, nr 8, 8 января; П. Пильский, Русские поэты в Польше, „Сегодня” 1937, nr 291, 23 октября, http://www.russianresources.lt/archive. html (05.03.2014).

7 I.A. Ndiaye, „Маленькие храбрые женщины...”, s. 54. 
twórczość jest właściwie nieznana dzisiejszym czytelnikom. Jeśli nie liczyć lakonicznych biogramów i nielicznych wierszy, które pojawiły się w słownikach i antologiach, opublikowanych na przełomie XX i XXI wieku w Rosji, USA i Polsce ${ }^{8}$, oraz kilku akapitów poświęconych Sienickiej w artykule polskiej badaczki ${ }^{9}$, należy stwierdzić, że literackie dokonania poetki i pisarki pozostawały dotąd poza zainteresowaniami badaczy. Niniejszy tekst jest próbą wypełnienia tej luki, ma na celu przybliżenie twórczej sylwetki Sienickiej, ogólną charakterystykę tematyki i poetyki jej wierszy.

Z dostępnych źródeł wyłania się nader skąpa, wręcz fragmentaryczna biografia poetki. Data jej urodzin, rok 1890, opatrzona jest w nich znakiem zapytania, o miejscu urodzin opracowania w ogóle milczą. Niewiele wiadomo o latach młodości Sienickiej. Ukończyła gimnazjum w Żytomierzu, wiersze zaczęła pisać jako jego uczennica. Zainteresowania literackie wyniosła z domu rodzinnego, wśród jej przodków był między innymi profesor Uniwersytetu Moskiewskiego, który zajmował się tłumaczeniem poezji antycznej i utworów Horacego. Ojciec Sienickiej, Erazm Wołyncew, parał się twórczością literacką, drukował w prasie rosyjskiej bajki. Nieznane są okoliczności, w jakich poetka wyjechała do Polski i osiadła na Wołyniu, w Równem. W 1939 roku przeniosła się, także z nieznanych powodów, do Warszawy. Niewykluczone, że nastąpiło to w wyniku zajęcia wschodnich rubieży Polski przez ZSRR 17 września 1939 roku, a przenosiny były de facto ucieczką przed władzą radziecką. W 1964 roku Sienicka zdecydowała się na powtórną (trzecią?) emigrację, wyjeżdżając do Stanów Zjednoczonych. Zmarła w Nowym Jorku w 1975 roku.

Nieco łatwiej zrekonstruować twórczą biografię Sienickiej, choć należy nadmienić, że wymaga ona jeszcze żmudnych poszukiwań w zbiorach ukraińskich, litewskich i polskich bibliotek, bowiem dorobek literacki poetki, rozproszony w dziesiątkach przedwojennych i powojennych czasopism i gazet, wciąż czeka na zebranie i uporząd-

8 „Вернуться в Россию - стихами...”. 200 поэтов эмиграции. Антология, сост. В. Крейд, Республика, Москва 1995, s. 614; В. Крейд (red.), Словарь поэтов русского зарубежья, Издательсвто Русского христианского гуманитарного института, Санкт Петербург 1999, s. 64-65; Е.А. Александров, Русские в Северной Америке. Биографический словарь, Конгресс Русских Американцев, Хэмден-Сан-Франциско-Санкт Петербург 2005; I.A. Ndiaye (red.), Poetycka Atlantyda. Antologia liryki kobiecej „pierwszej fali” rosyjskiej emigracji, Wydawnictwo Uniwersytetu Warmińsko-Mazurskiego, Olsztyn 2006, s. $371-373,410$.

9 I.A. Ndiaye, „Маленькие храбрые женщины...”, s. 54-55. 
kowanie. Poważnym utrudnieniem tych studiów jest fakt, że prywatne archiwum Sienickiej spłonęło w czasie Powstania Warszawskiego.

Poetka przez cały niemal okres międzywojnia mieszkała w Równem, które z perspektywy „rosyjskiej Warszawy”, Wilna i Lwowa było postrzegane jako kulturalna prowincja. Miasto nosiło co prawda miano „centrum handlowego całego Wołynia”, jednak pod względem poziomu i intensywności życia literackiego nie mogło się równać z wymienionymi ośrodkami. Równe, z jednej strony rażące nawet swoich mieszkańców „prymitywizmem ulic” ${ }^{10}$, z drugiej zaś - przejawiające „tendencje nieustannego rozwoju i chęci przekształcenia się w miasto kulturalne, uporządkowane, obfitujące w skwery, pełne zieleni" wpisywało się w pełen sprzeczności klimat kulturalny Wołynia, o którym pisał mieszkający tam kilkanaście lat Lew Gomolicki:

из опустевшей, взрытой снарядами, окропленной кровью расстрелов земли бесшумно всходил столетний посев мысли. Знаете ли вы эти деревушки, несущие имена древних славянских божеств; овраги, где к копытам несущихся коз скатываются ржавые тысячелетние черепа и мамонтов бивень прободал пласт мела; средневековые башни, слышавшие латинскую и греческую речь религиозных диспутов; стук гутенберговских машин и шелест первопечатных книг? Тут сама земля вслух философствует сама с собою и говорит стихами. Сколько было среди моих сверстников домашних философов, еретиков, героев духа, подвижников и поэтов! Поэтов больше всего ${ }^{12}$.

Intensywna praca twórcza i wielotorowa działalność literacka, jaką Sienicka prowadziła w Równem, potwierdzały zacytowaną konstatację Gomolickiego. W domu poetki spotykali się członkowie miejscowego kółka literackiego: Iwan Kulisz, M[?]. Wesołowska, A[?]. Maj. Na zebrania przyjeżdżali poeci z Wilna (Siergiej Naljancz, Tamara Sokołowa), Warszawy (Jewgienij Wadimow) i Kijowa (A[?]. Richter). Atmosferę spotkań w Równem, które odbywały się pod przewodnictwem Sienickiej, opisywał cytowany już Gomolicki, podkreślając, że niczym nie ustępowały one dyskusjom prowadzonym w „rosyjskim Paryżu”:

мне было суждено провести двя „дня стихов” в поэтическом доме, у Лидии Эразмовны Сеницкой (где стихи пишут чуть ли не всею семею - во

${ }^{10}$ R. Janisławski, Kilka słów o Równem, [n.s.], Równe 1939, http://www.antoranz. net/BIBLIOTEKA/ROWNE/ROWNE-o.HTM (27.04.2014).

${ }_{11}$ Tamże.

12 Л.Н. Гомолицкий, Провинциальные мысли, „Меч” 1936, nr 37, 13 сентября, https://lit.wikireading.ru/35801 (17.04.2018). 
всяком случае, и мать, и сын, - где сам воздух такой лирико-дактилический, где в архивах письменных столов лежат газетные вырезки и терпеливо переписанные от руки сборники известных поэтов). [...] Решать судьбы поэзии в Ровно! Что же, если там в „простоте речей” обитают „парнасские девушки”, Музы. [...] может быть, наша далекая ровенская беседа была плодотворней монпарнасских диспутов $[. . .]^{13}$.

Sienicka współpracowała z rosyjskimi periodykami, ukazującymi się w przedwojennej Polsce: warszawskimi („Меч”, „Наше время”, „Русский голос”, „Воскресное чтение”) i wileńskimi („Утес”, „Русское слово”, „Новая искра”). Jej utwory były drukowane również w rosyjskiej prasie w Harbinie. Publikowała nie tylko wiersze, opowiadania i sztuki, ale także recenzje literackie. Zajmowała się również tłumaczeniami: przełożyła na język rosyjski między innymi utwory Leconte'a de Lille'a i Leopolda Staffa. Po II wojnie światowej związała się wychodzącym w Łodzi czasopismem „Русский голос”.

Pomimo niemałego dorobku poetyckiego Sienicka nie doczekała się odrębnego tomu wierszy. Przygotowana do druku książka zatytułowana Вторая жизнь nie ukazał się, jej rękopis (maszynopis?) spłonął w czasie Powstania Warszawskiego. Jedyny tomik pod tytułem Ледяные узоры ujrzał światło dzienne dopiero w trzy lata po śmierci Sienickiej, w 1978 roku. Fakty te nabierają szczególnego znaczenia w kontekście słów samej poetki, według których publikacja zbioru jest dla autora „zawsze zdecydowanym krokiem, prawdziwym sprawdzianem jego literackiej dojrzałości”, ponieważ „poszczególne rozrzucone wiersze, nawet jeśli często spotykane w druku, nie dają twórcy możliwości zaprezentowania prawdziwego oblicza"14.

Poza publikacjami w prasie wiersze Sienickiej zostały włączone do dwóch ogólnopolskich antologii poezji rosyjskiej, jakie ogłoszono w naszym kraju w latach trzydziestych. Opublikowany w 1930 roku Сборник русских поэтов в Польше był pierwszym w rosyjskiej diasporze międzywojnia przeglądem poezji emigracyjnej. Zamieszczono w nim wzbogacone biogramami i fotografiami autorów wiersze siedemnastu poetów uznanych za najbardziej reprezentatywnych dla poezji emigracji rosyjskiej w Polsce. Tom przygotowywano w pośpie-

${ }^{13}$ Tamże. Warto nadmienić, że równieńskie zebrania poetyckie Sienicka upamiętniła w wierszu Невольно с грустью вспоминаю... .

14 Л. Сеницкая, Монахиня Мария. Стихи. Издательство „Петрополис”. Берлин [recenzja w:], „Русское слово” 1939, nr 113 (2230), 15 мая, http://www. russianresources.lt/archive/Senic/Senic_2.htm (27.04.2014). Tłum. cytatu - J.B. 
chu, o czym świadczyły liczne redakcyjne przeoczenia i niedociągnięcia, przy czym jego redaktor Siemion Witiaziewski nie zadał sobie trudu, by otrzymać oficjalną zgodę autorów wierszy na ich publikację $e^{15}$. Recenzenci antologii, wypominając większości poetów brak wiedzy w zakresie języka poetyckiego i „elementarnych zasad wersyfikacji”, krytykując ogólny niski poziom utworów, zwracali jednak uwagę, że na ich tle pozytywnie wyróżniają się wiersze Gomolickiego, Pałtijela Kacenelsona i Sienickiej ${ }^{16}$.

Twórczość poetki wysoko ocenili także recenzenci antologii rosyjskiej poezji w Polsce, wydanej staraniem Związku Rosyjskich Pisarzy i Poetów w Polsce w 1937 roku $^{17}$. W jej skład weszło trzydziestu pięciu autorów, każdy z nich zaprezentował jeden wiersz. Zastrzegając, że na podstawie tak skąpego materiału trudno wydawać sąd o jego twórcy, krytycy pisali, że Sienicka należy do najbardziej utalentowanych poetów rosyjskiej diaspory w Polsce ${ }^{18}$ i wymieniali jej nazwisko na ogół tuż po Gomolickim i Aleksandrze Kondratjewie, mających status „gwiazd pierwszej wielkości”. Zamieszczony w antologii wiersz Sienickiej Поля широкой шляпы пилигрима..., liryczny portret pielgrzyma, który przemierzając szumne ulice obcych miast, zaświadcza swoim życiem sens pokory i poświęcenia („так он идет [...] о подвиге смиренья - терпеливо несущий весть в потоке грешных дней”"19), budził uznanie obrazowością, gęstością barw i przenikliwością, był odbierany jako przejaw poetyckiej dojrzałości, fascynacji poetki sprawami ducha ${ }^{20}$.

Wskazywano także, że poezja Sienickiej cechuje się „zawężonym kręgiem wrażeń duchowych" ${ }^{21}$, że pozostaje w „świecie obrazów raczej intymnych niż jaskrawych"22. Właściwości te tłumaczono niekiedy jako specyficzne „piętno prowincji”, nieuchronny rezultat geograficznego oddalenia od ośrodków kulturalnych emigracji rosyjskiej. Trudno jednak zgodzić się z taką argumentacją, bowiem także w powojennej twórczości, powstającej pod inną szerokością geograficzną, poetka pozostawała w kręgu tej samej tematyki, zaś jej wiersze

\footnotetext{
15 Л. Белошевская, П. Мицнер, Л. Флейшман, Лев Гомоликий..., s. 56.

${ }^{16}$ С. Нальянч, Жуткая книга („Сборник русских поэтов в Польше”), „За Свободу!”, 23.06.1930.

${ }_{17}$ Антология русской поэзии в Польше, [b.w.], Варшава 1937.

${ }^{18}$ П. Пильский, Русские поэты в Польше...

${ }^{19}$ Антология русской поэзии в Польше, s. 27.

${ }^{20}$ П. Пильский, Русские поэты в Польше...

${ }^{21}$ Н. Волковыский, Русские литераторы в Польше...

${ }^{22}$ Tamże.
} 
odznaczały się jak dawniej subtelnością w psychologicznym rysunku podmiotu lirycznego ${ }^{23}$. Wydaje się, że właściwą poezji Sienickiej kameralność, intymność, postrzegać należy raczej w kategoriach estetycznych: jako wyraz osobowości twórczej, przejaw właściwego dla niej rozumienia i wartościowania świata, być może także - jak pisze polska badaczka - jako wyróżnik tzw. literatury kobiecej, mającej własny „rytm”, ekspresję, wrażliwość, odmienny od męskiego sposób reagowania na rozmaite zagadnienia świata zewnętrznego ${ }^{24}$.

Wskazane cechy poezji Sienickiej uwidaczniają się z całą mocą w głęboko osobistym przetwarzaniu tematów podsuwanych przez złożoną, nasyconą tragizmem rzeczywistość historyczną. W wierszach inspirowanych wydarzeniami dziejowymi próżno szukać bezpośrednich odgłosów przeżytych kataklizmów obu wojen światowych, które wywarły przecież ogromny wpływ na życie poetki, czyniąc z niej podwójną emigrantkę. Wielkie sprawy współczesnego świata są jednak obecne w jej wierszach, tyle tylko, że w postaci mocno przefiltrowanej przez świadomość autorki, odsączonej z doraźnych haseł politycznych, narodowych czy społecznych, nierzadko ukryte za pejzażem bądź czytelną, ale sugestywną metaforą. W taki właśnie sposób odczytać można wiersz Октябрьские дни (1931). Konwencjonalny pejzaż jesienny z nieodłącznymi atrybutami w rodzaju opadających liści i opustoszałych pól współgra z nastrojem „ja” lirycznego, w którym dominują uczucia zadumy, nostalgii i żalu. Smutek podmiotu ma jednak, jak czytamy w pierwszym wersie, „niejedno oblicze” („Многолика Печаль в поминальные дни" ${ }^{25}$ ), jest wywołany nie tylko przez upływ czasu, ale i wspomnienie niedawnych wydarzeń historycznych napływające w kolejną „rocznicę szaleństw i hańby” („годовщину безумств и позора").

Na analogicznym pomyśle opiera się wiersz Ночной ветер (1935). $\mathrm{W}$ rozbudowanym obrazie nocnej wichury przełamują się wspomnienia i asocjacje z ojczyzną poetki. Wykreowany w utworze pejzaż łączy w sobie dosłowność zjawiska atmosferycznego i znaczenie przenośne,

${ }^{23}$ Por. w recenzji pośmiertnego tomu Sienickiej: „Стихи Л. Волынцевой - это сентябрьский листопад или декабрьская метель. Стихи эти напоминают свечи, зажженные в маленькой, отдаленной от городских шумов часовенке перед Богоматерью 'Утоли мои печали” (Словарь поэтов..., s. 65, za: I. A. Ndiaye, „Маленькие храбрые женщины...”, s. 55).

24 Więcej na ten temat zob.: I.A. Ndiaye, „Маленькие храбрые женщины...”.

25 Л. Сеницкая, Октябрьские дни, http://www.russianresources.lt/archive/Senic/ Senic_1.html\#1 (05.03.2014). Pozostałe wiersze Sienickiej cytuję, o ile nie podano inaczej, według tegoż adresu internetowego. 
to zaś - za sprawą przede wszystkim ostatniej strofy, ale także wcześniejszych „sygnałów” - odczytać należy jako echo przewrotu bolszewickiego, który wstrząsnął Rosją:

\section{Как варвар, разгульной ватагой Ворвавшийся в сон и покой, Безумствовал с дикой отвагой, На улицах ветер ночной; \\ [...] Но вихрям открыта широко \\ Мехами стесненная грудь, - То с Родины ветер, с Востока; Им сладко до боли вздохнуть.}

Poetka nawiązała w wierszu do wielowiekowej tradycji kulturowej, zgodnie z którą wiatr jest między innymi symbolem zagrożenia, wojny, cierpienia ${ }^{26}$. Ponadto, jak można przypuszczać, odwołała się do motywów utraconego kraju ojczystego, ogarniętego „szaleństwem bolszewizmu", ale wciąż bliskiego emigrantom (warto przypomnieć w tym kontekście chociażby tytuł głośnej powieści Aleksieja Riemizowa Rosja wichrem niesiona [Взвихренная Русь, 1927]).

Właściwy twórczości Sienickiej model przeżywania polegający na ujawnianiu stanu ducha podmiotu lirycznego poprzez obraz przyrody, odnajdujemy w wierszu Д. Д. Б. (1931), podejmującym problematykę wygnania. Za inicjałami, stanowiącymi dedykację i zarazem specyficzny tytuł utworu, kryje się Dorofiej Dorofiejewicz Bochan, tłumacz literatury polskiej na język rosyjski, krytyk, poeta, organizator życia literackiego w Wilnie, w okresie dwudziestolecia międzywojennego wydawca wileńskiego miesięcznika poświęconego literaturze i sztuce „Утес”, w którym Sienicka publikowała wiersze. Bochan kierował ponadto kółkiem autorów działającym przy Sekcji Literacko-Artystycznej Wileńskiego Towarzystwa Rosyjskiego (Виленское русское общество), którego Sienicka była honorowym członkiem. Znajomość obojga twórców wymaga jeszcze badań, z dużą dozą prawdopodobieństwa można jednak założyć, że w ich rozmowach przewijał się temat sytuacji rosyjskich emigrantów w Polsce. Niewykluczone, że dedykowany Bochanowi wiersz Sienickiej jest pokłosiem takich właśnie rozmów. Otwierający go obraz zabłąkania w leśnej gęstwinie, nawoływania współtowarzyszy drogi, jest w istocie nieskomplikowaną metaforą życia na obczyźnie i życia ludzkiego w ogóle:

${ }^{26}$ Por. „wiatr” [hasło w:] W. Kopaliński, Stownik symboli, Oficyna Wydawnicza Rytm, Warszawa 2006, s. 458-461. 


\section{POETYCKI ŚWIAT LIDII SIENICKIEJ}

В житейских зарослях, давно, Без верных троп, в изгнаньи, Бредем мы; и жутко и темно, Томит вокруг молчанье.

Но вот „Ау!” в письме живом Летит с опушки дальней; Порой сверкают рифмы в нем, Как светляки в тумане.

Osamotnienie i zbłądzenie podmiotu lirycznego - zaznaczmy, że zbiorowego - jest motywowane przede wszystkim przebywaniem na obcej ziemi, z dala od ojczyzny. Wydaje się jednak, że poetka odwołuje się także do starotestamentowej koncepcji ziemskiego bytu jako wygnania, a zarazem posługuje się obrazem lasu, by odzwierciedlić duchowe zagubienie człowieka. Z kolei wzmianka o wierszach odnajdywanych w listach od znajomych („rymy-świetliki we mgle”) pozwala domyślić się w „ja” lirycznym odbicia losów realnego poety, co uruchamia dodatkowe konteksty utworu: z jednej strony romantyczne wyobrażenie twórcy-wygnańca $\mathrm{w}$ społeczeństwie, $\mathrm{z}$ drugiej - żywo dyskutowaną w kręgach emigracji „pierwszej fali” kwestię geograficznego rozproszenia jej przedstawicieli, powodującego postępującą atomizację życia literackiego rosyjskiej diaspory ${ }^{27}$. Obraz poetów-wygnańców, nawołujących się i odnajdujących w mroku, oraz wyraźnie pozytywna tonacja emocjonalna wiersza miały zaświadczać o żywotności literatury emigracyjnej wciąż rozwijającej się pomimo licznych przeciwności.

Przeświadczenie o twórczym potencjale literatury „pierwszej fali”, ale także o sensie i pięknie ludzkiego życia jako takiego, poetka wyraziła także w utworze Ты о жизни, нашей жизни краткой... (1931). Nadała mu odmienną od dotychczas omówionych formę liryki inwokacyjnej, w pełnych pasji słowach - co sygnalizuje nagromadzenie zdań wykrzyknikowych - atakując nienazwanego adresata za jego postawę duchową i jednocześnie prezentując własne argumenty. Po-

${ }^{27}$ Por.: „Nie można nie widzieć tego, co najważniejsze: że usypisko pisarzy nie czyni jeszcze literatury, że literatura żyje tylko tam, gdzie pisarze nie są rozsypani, lecz zebrani; gdzie, niby w porze ruszenia lodów, trącają o siebie, spiętrzają się, oddzielają i przeszkadzają sobie nawzajem, sytuują swe inspiracje w szerokim nurcie narodowego życia” (Ф.А. Степун, Советская и эмигрантская литераmyра 2O-x годов, w: tegoż, Встречи, Товарищество Зарубежных Писателей, München 1962, s. 190, za: A. Drawicz, Inna Rosja. Genealogia rosyjskiej literatury emigracyjnej, Nowa 2, Warszawa 1980, s. 17). 
czuciu bezsensu istnienia, wszechogarniającemu zmęczeniu życiem, beznadziei i smutkowi - nastrojom powszechnym wśród rosyjskich emigrantów i często ewokowanym w ich twórczości - poetka przeciwstawia chrześcijańską koncepcję ludzkiego bytu - daru Stwórcy. Wdzięczność za Bożą szczodrość łączy się w wierszu z niezachwianą wiarą w sens Jego zamysłu, a więc także w wartość i zasadność cierpienia. Podjęty w utworze temat fundamentalnych problemów ludzkiej egzystencji wyrasta z rozmyślań nad niedolami emigracyjnej tułaczki.

Poetka chętnie porusza się w kręgu zagadnień ponadczasowych, uniwersalnych, jak miłość, powołanie poetyckie, więź człowieka z przyrodą i przemijanie. W jej perspektywie motywy te nierzadko wiążą się ze sobą: obrazy przyrody stają się pretekstem do wspomnień o minionym uczuciu (Белая сирень, 1931) lub też ekwiwalentem stanu duchowego „ja” lirycznego (Отчего на сапфирное небо весеннее..., 1931; Тот день, 1931; Среди полей, b.d.), przyroda jest także źródłem twórczej inspiracji (За город выйти, и тихо, без цели..., b.d.). W liryce miłosnej Sienickiej ujawnia się z całą mocą właściwa poetce subtelność obrazowania: odzwierciedlając różne etapy i odcienie uczucia, autorka nie nazywa go wprost, a jedynie sugeruje, ukrywa za łatwymi do rozszyfrowania metaforami przyrodniczymi. Przy czym Sienicką interesuje nie zapis konkretnych „przypadków” - własnych czy cudzych - miłosnego uniesienia, lecz uchwycenie istoty uczucia, stworzenie jego ponadindywidualnego lirycznego studium. Służy temu rezygnacja ze szczegółowego portretu bohaterów lirycznych oraz przesunięcie podmiotu na drugi plan, za świat przedstawiony wierszy.

W omawianej poezji stale przewija się także motyw autotematyczny. Tworzenie jest dla ,ja” lirycznego wierszy Sienickiej czynnością naturalną i zarazem konieczną do przetrwania ( 3 а город выйти, и тихо, без цели...), stanowi dar Boży, któremu nie sposób się sprzeniewierzyć, bowiem nadaje on życiu podmiotu wartość niezbywalną, rekompensuje samotność (Д. Д. Б.) i pozwala znieść trudy wygnania (Ты о жизни, нашей жизни краткой...). Toteż świadomość ludzkiej przemijalności, o której poetka pisze między innymi w wierszu Elegia (Элегия, b.d.), nie tylko wzbudza pragnienie dokonania u kresu życia rozmaitych podsumowań, ale także zwiększa potrzebę, by wiele spraw „ocalić od zapomnienia”:

Успеть ли венцом драгоценным сплести

Созвучий живые караты,

Успеть ли последнее бросить „Прости!”

Всему, что приснилось когда-то... 
Ważne miejsce w poezji Sienickiej zajmuje także tematyka inspirowana życiem codziennym. Podmiot liryczny omawianych wierszy żyje nie tylko wielkimi problemami swojego narodu, ale także troskami dnia powszedniego, jest nie tylko Rosjanką, emigrantką, poetką, wciela się również w role bardziej prozaiczne. Poetycki świat Sienickiej jest rozpięty, jak czytamy w jednym z jej tekstów, pomiędzy „nieogarnioną panoramą gwiazd” i „rodzimym przestworem ziemskiej drogi” (Чрез окно, что лунными лучами..., b.d.).

Wprowadzając do swoich utworów przyziemną rzeczywistość, Sienicka potrafi ją z wdziękiem i przekonująco poetyzować, nadawać jej piętno „innego, osobliwego widzenia i odczuwania otaczającego świata" ${ }^{28}$. W jednym z wierszy (Уже закончен круг дневнъх забот..., b.d.) zwykłe gospodarskie czynności powtarzane regularnie u schyłku dnia: zamykanie drzwi i okien, ustalanie obiadu na następny dzień, przeistaczają się niemalże w rytuał chroniący domostwo ,ja” lirycznego przed niepowodzeniem, zapewniający mu pomyślność:

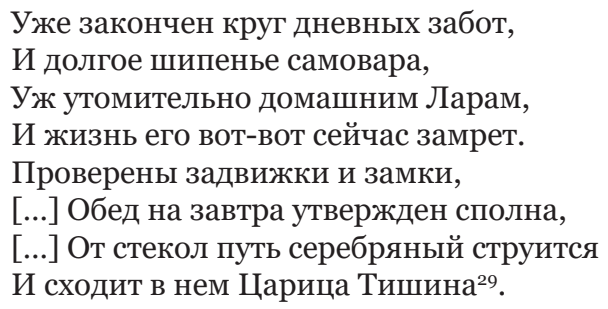

Уже закончен круг дневных забот, И долгое шипенье самовара,

Уж утомительно домашним Ларам, И жизнь его вот-вот сейчас замрет. Проверены задвижки и замки, [...] Обед на завтра утвержден сполна, [...] От стекол путь серебряный струится И сходит в нем Царица Тишина ${ }^{29}$.

W innym utworze (Мигрень, b.d.) podobnemu zabiegowi „uniezwyklenia” tego, co zwyczajne, zostaje poddana także „prorocza migrena”, pozwalająca podmiotowi lirycznemu przenieść się z „beznadziei codzienności" do innego świata, przesyconego blaskiem słońca i zapachem miodu.

Niezależnie od tego, czy poetka podejmuje ważkie problemy otaczającej ją rzeczywistości, czy pisze o tematach wiecznych, czy wreszcie zwraca się ku sprawom osobistym i zwykłym, jej wiersze cechuje szczerość i uczciwość, „mówienie bez maski i bez patosu” ${ }^{\circ}$. Z naturalnością wypowiedzi współgra prostota formy, będąca wynikiem oszczędnego stosowania środków wyrazu artystycznego, precyzji w doborze słów, unikania zbędnych ozdobników stylistycznych.

\footnotetext{
${ }^{28}$ I.A. Ndiaye, Wstęp, w: Poetycka Atlantyda..., s. 13.

${ }^{29}$ Za: Poetycka Atlantyda..., s. 371.

${ }^{30}$ I.A. Ndiaye, Wstęp..., s. 13
} 
W warstwie wersyfikacyjnej analizowane utwory nawiązują do tradycji złotego wieku poezji rosyjskiej, poetka preferuje bowiem regularne rozmiary sylabotoniczne.

Poezja Sienickiej jest skromnym, ale wartościowym świadectwem popaździernikowej emigracji, lirycznym zapisem kondycji człowieka, doświadczonego przez kataklizmy dziejowe. Spuścizna poetki ze wszech miar zasługuje na to, by po latach zapomnienia ponownie włączyć ją do dziedzictwa literatury rosyjskiej.

\section{REFERENCES}

Agapkina, Tat'yana. Tsybenko, Ol'ga. "Materyaly k biografii Leona (L'va) Gomolitskogo." Studia Polonorossica: K 8o-letiyu Eleny Zakharovny Tsybenko. Sbornik statey. (Ed.) Khoryev, Viktor. Moskva: Izdatel'stvo Moskovskogo Universiteta, 2003. 468-479 [Агапкина, Татьяна. Цыбенко, Ольга. "Материалы к биографии Леона (Льва) Гомолицкого.” Studia Polonorossica: K 8o-летию Елены Захаровны Цыбенко. Сборник статей. (Ред.) Хорев, Виктор. Москва: Издательство Московского Университета, 2003. 468-479].

Aleksandrov, Evgeniy. Russkiye v Severnoy Amerike. Biograficheskiy slovar'. Khamden-San Francisco-Sankt Peterburg: Kongress Russkikh Amerikantsev, 2005 [Александров, Евгений. Русские в Северной Америке. Биографический словарь. Хэмден-Сан-Франциско-Санкт Петербург: Конгресс Русских Американцев, 2005].

Antologiya russkoy poezii v Pol'she. Varshava: [n.s.], 1937 [Антология русской поэзии в Польше. Варшава: [n.s.], 1937].

Beloshevskaya, Lubov'. Mitzner, Piotr. Fleishman, Lazar. "Lev Gomolitskiy i russkaya literaturnaya zhizn' v mezhvoennoy Pol'she." Gomolitskiy, Lev. Sochinenya russkogo perioda. V triokh tomakh. Moskva: Vodoley, 2011. I: 5-282 [Белошевская, Любовь. Мицнер, Петр. Флейшман, Лазарь. “Лев Гомолицкий и русская литературная жизнь в межвоенной Польше.” Гомолицкий, Лев. Сочинения русского периода. В трех томах. Москва: Водолей, 2011. I: 5-282].

Drawicz, Andrzej. Inna Rosja. Genealogia rosyjskiej literatury emigracyjnej. Warszawa: Nowa 2, 1980.

Gomolitskiy, Lev. "Provintsyalnye mysli." Mech 1936, no. 37, 13 sentyabrya [Гомолицкий, Лев. „Провинциальные мысли.” Меч 1936, № 37, 13 сентября] $<$ https://lit.wikireading.ru/35801>.

Janisławski, Roman. Kilka słów o Równem. Równe: [s.n.], 1939 <http://www.antoranz.net/BIBLIOTEKA/ROWNE/ROWNE-o.HTM>.

Kopaliński, Władysław. Słownik symboli. Warszawa: Oficyna Wydawnicza Rytm, 2006.

Kulczycka-Saloni, Janina. "Przedwojenne i powojenne pisarstwo Leona Gomolickiego." Przeglad Humanistyczny 1995, no. 4. 47-57.

Mitzner, Piotr. Fleishman, Lazar. Metamorfozy Lwa (Leona) Gomolickiego. Transl. Szczęsny, Robert. Warszawa: Wydawnictwo Uniwersytetu Kardynała Wyszyńskiego, 2015. 


\section{POETYCKI ŚWIAT LIDII SIENICKIEJ}

Nal'yanch, Sergey. “Zhutkaya kniga ('Sbornik russkikh poetov v Pol'she').” Za Svobodu!, 23.06.1930 [Нальянч, Сергей. “Жуткая книга ('Сборник русских поэтов в Польше')”. За Свободу!, 23.06.1930].

Ndiaye, Iwona Anna. “Маленькие храбрые женщины...'. Poezja kobieca pierwszej fali emigracji rosyjskiej w Polsce.” Acta Polono-Ruthenica 2002, no. VII. 45-58.

Ndiaye, Iwona Anna. "Russkaya emigratsyonnaya poeziya na stranitsakh varshavskogo 'Mecha' (1934-1939)” [„Русская эмиграционная поэзия на страницах варшавского 'Меча' (1934-1939)”] (Ed.) Ksenicz, Andrzej. Stowiańszczyzna Wschodnia: twórczość artystyczna a doświadczenia zbiorowe. Zielona Góra: Wydawnictwo WSP, 1998. 71-76.

Obłąkowska-Galanciak, Iwona. „Gorzkie gody...”. Publicystyczna i literacka działalność Dymitra Fiłosofowa na emigracji. Olsztyn: Wydawnictwo Uniwersytetu Warmińsko-Mazurskiego, 2001.

Pil'skiy, Pyotr. "Russkiye poety v Pol'she.” Segodnya 1937, no. 291, 23 oktyabrya [Пильский, Петр. „Русские поэты в Польше.” Сегодня 1937, no. 291, 23 октября] <http://www.russianresources.lt/archive.html>.

Poetycka Atlantyda. Antologia liryki kobiecej „pierwszej fali” rosyjskiej emigracji. (Ed.) Ndiaye, Iwona Anna. Olsztyn: Wydawnictwo Uniwersytetu Warmińsko-Mazurskiego, 2006.

Senitskaya, Lidya. "Monakhinya Mariya. Stikhi. Izdatel'stvo 'Petropolis'. Berlin.” Russkoye slovo 1939, no. 113 (2230), 15 тауа [Сеницкая, Лидия. "Монахиня Мария. Стихи. Издательство ‘Петрополис'. Берлин.” Русское слово 1939, no. 113 (2230), 15 мая] <http://www.russianresources.lt/archive/Senic/Senic_2.html>.

Senitskaya, Lidya. "Oktyabr'skiye dni." [Сеницкая, Лидия. “Октябрьские дни”] $<$ http://www.russianresources.lt/archive/Senic/Senic_1.html\#1>.

Sielicki, Franciszek. "Mereżkowski w Polsce międzywojennej." Przegląd Humanistyczny 1973, no. 3. 105-127.

Skrunda, Wiktor. "Echa 'gniewnych jambów' w poemacie Lwa Gomolickiego 'Warszawa' (1934).” Studia Rossica XI 2000. 187-197.

Skrunda, Wiktor. "Rosyjski uchodźca na polskim bruku. O poemacie Lwa Gomolickiego ‘Warszawa' (1934).” Studia Rossica X 2000. 91-127.

Skrunda, Wiktor. "Zamysł poematu Lwa Gomolickiego 'Warszawa' w świetle inwektyw Karola Radka i nauk mnicha Ewagriusza." Studia Rossica XII 2001. 215-228.

Slovar' poetov russkogo zarubezhya. (Ed.) Kreyd, Vadim. Sankt Peterburg: Izdatel'stvo Russkogo khristianskogo gumanitarnogo instituta, 1999 [Словарь поэтов русского зарубежъя. (Ред.) Крейд, Вадим. Санкт Петербург: Издательство Русского христианского гуманитарного института, 1999].

Stiepun, Fyodor. "Sovetskaya i emigrantskaya literatura 20-kh godov.” Stiepun, Fyodor. Vstriechi. München: Tovarishchestvo Zarubezhnykh Pisateley, 1962. 187202 [Степун, Федор. “Советская и эмигрантская литература 20-х годов.” Степун, Федор. Встречи. München: Товарищество Зарубежных Писателей, 1962. 187-202].

"Vernutssa $v$ Rossiyu - stikhami...". 200 poetov emigratsii. Antologiya. Sost. Kreyd, Vadim. Moskva: Respublica, 1995 [„Вернуться в Россию - стихами...”. 200 поэтов эмиграции. Антология. Сост. Крейд, Вадим. Москва: Республика, 1995].

Volkovyskiy, Nikolay. "Russkiye literatory v Pol'she.” Segodnya 1937, no. 8, 8 yanvarya [Волковыский, Николай. “Русские литераторы в Польше.” Сегодня 1937, no. 8, 8 января] <http://www.russianresources.lt/archive.html>. 
Zienkiewicz, Tadeusz. "Dorofiej Bochan - tłumacz literatury polskiej na język rosyjski i krytyk.” (Ed.) Bartoszewicz, Albert. Polsko-wschodniostowiańskie powiązania kulturowe, literackie i językowe. 1. Literatura i kultura. Olsztyn: Wydawnictwa Wyższej Szkoły Pedagogicznej, 1994. 127-134.

Zienkiewicz, Tadeusz. "I nas izgnannikow w molitwach pomiani...'. (O poezji emigracji rosyjskiej w Polsce międzywojennej).” Studia Rossica X 2000. 76-90. 